\title{
Energy optimization analysis of archetype public buildings - Results from SHERPA European Project
}

\author{
Tullio de Rubeis ${ }^{1}$, Iole Nardi $^{2}$, Domenica Paoletti ${ }^{1}$, and Dario Ambrosini ${ }^{1}$ \\ ${ }^{1}$ University of L'Aquila, Department of Industrial and Information Engineering and Economics \\ (DIIIE), Piazzale Pontieri 1, Monteluco di Roio, I 67100 L'Aquila, Italy \\ ${ }^{2}$ ENEA Casaccia Research Center, via Anguillarese, 301, I 00123 S.M. di Galeria, Rome, Italy
}

\begin{abstract}
In this paper, the main results obtained for the identification of energy efficiency measures (EEMs) in archetype public buildings selected by the Abruzzo Region within the European Project SHERPA (SHared knowledge for Energy Renovation in buildings by Public Administration), a three-year project involving 12 partners from the Mediterranean area, are presented.The analysis presented in this work was carried out on 12 public buildings, with different intended use, located in the four provinces of the Abruzzo Region characterized by different climate conditions. For each building, a complex work of documents acquisition has been carried out together with the regional coordinators of the Project. These documents have allowed the energy assessment of the selected buildings in their current condition. The second phase of the study has instead focused on the effects resulting from the application of EEMs on both passive and active components, in terms of energy savings and greenhouse gas (GHG) emissions reduction. The results obtained have permitted to compare different public buildings, in different climate conditions, identifying EEMs and achievable results that may be useful to policy makers for the identification of appropriate energy optimization strategies and financial instruments for their implementation.
\end{abstract}

\section{Introduction}

The building sector, considered one of the main contributors to GHGs emissions due to the large amounts of energy consumed, requires significant efforts towards the identification of energy optimization strategies and interventions. In particular, the public building sector, notoriously energy intensive due to high occupancy rates, requires special attention.

In this sense, ambitious goals have been set for 2050, aiming to a decarbonization and mitigation of ongoing climate change [1]: the pathway to this transition passes through the energy efficiency renovation, renewable energy sources (RES) adoption and integration, thermal energy plant revamping in light of heat pump installation, district heating and cooling systems, energy storage, and smart systems. This will lead to electrified and flexible buildings 
(meaning a set of buildings) which interact for needs and productions, but it is clear that this shift (which is ongoing) is still slow, also due to a building stock often made up of poorly performing historical buildings [2].

To promote and accelerate the energy renovation (whose rate is around $1 \%$ of buildings per year), several financial and fiscal instruments have been deployed across the EU. These schemes (whether private and public financial and fiscal mechanisms) have been set differently for the building types (residential, public, and commercial), according to Member States policies [3]. For instance, in Countries like Finland, Ireland, Estonia, and Romania the public support is devoted to residential buildings only; only three Countries (France, Belgium and Italy) deployed all types of instruments (grants/loans/tax deduction) for all kind of buildings [3].

Within this framework, it is crucial to share knowledge, experiences and know-how on energy renovation policies, measures and goals, and a proper knowledge of the local building stock features (thus having databases, in situ assessments, building archetypes, etc.) to establish some what a "starting point" and a "target point" with reliable margins of achievement [4].

This, of course, requires a network of stakeholders: from Countries to Regions, from local administrations to Municipalities, all kept together to join the efforts. In this sense, and in the cooperation perspectives, European projects play a key role to set a common table where Countries can share their expertise. This is also the aim of the SHERPA project which is an Interreg MED project co-financed by the European Regional Development Fund that supports the development of building renovation projects in public buildings' stock of the involved partners. SHERPA is a testing and capitalizing project, that also aims at transferring tools and results from regional experiences. To do this, SHERPA aimed at reinforcing capacities of Administrations in the Mediterranean area (both at regional and sub-regional level) to set projects and plans for energy renovation of the building stock, as well as to address the related implementation issues.

In Italy, three regions participated (one of the North - Emilia Romagna - and two of the central - Lazio and Abruzzo) and, thanks to a partnership, the Authors have helped the Abruzzo Region with the building assessment and renovation strategies identification. Particularly, 12 public buildings having different intended use and located among the four provinces of L'Aquila, Teramo, Pescara, and Chieti, thus characterized by different climate conditions, were selected by the Region. For each building, and together with the regional coordinators of the Project, documents acquisition has been carried out to set the "starting point" of the renovation strategy. Therefore, detailed data analysis was carried out. Then, the results from the application of possible EEMs (on both passive and active components), in terms of energy savings and mitigation of GHGs emissions, were carried out.

Results allowed to compare those public buildings, and to identify optimization interventions and achievable results that may be useful to policy makers for the identification of appropriate energy optimization strategies and financial instruments for their implementation.

\section{Materials and methods}

As previously introduced, the Interreg MED European Project SHERPA is a cooperation project aimed to improve the energy efficiency of public buildings in Mediterranean area. SHERPA focused on strengthening the capacities of public administrations at the regional and sub-regional levels on energy efficiency of public buildings' stock. Twelve Mediterranean partners from Spain, France, Italy, Croatia, Malta, and Greece have been involved, including nine regional authorities (e.g., Government of Catalonia, Abruzzo Region, Lazio Region, Minister of Gozo, etc.) [5]. The SHERPA Project is therefore aimed 
at fostering the transnational sharing of information on energy efficiency in public buildings among the 12 partners, in line with the two European Directives: on energy performance (2010/31/EU) [6], and on energy efficiency of public buildings in the MED area $(2012 / 27 / \mathrm{EU})$ [7]. To describe the project in numbers, it is worth explaining that 12 partners were involved ( 8 form Mediterranean Regions and 4 ERB - Energy Renovation of Buildings - and EU networks), that in cascade engaged 50 regional and local administrations, accessing to a budget of 3.2 M€ for 39 months lasting project, developing 165 regional and local ERB projects [8].

\subsection{Methodology}

The methodology adopted in this work is divided into two macro-phases. The first involves the acquisition of the documents necessary for a detailed knowledge of the buildings under analysis. Considering number and size of the buildings to be analyzed, a checklist summarizing the main info was purposely conceived: this has allowed to make this phase as automatic as possible. Hence, together with the regional coordinators of the Project, the fundamental information concerning geometric characteristics, properties of the envelope opaque and transparent - and of the technological systems, including the possible presence of RES, have been identified. This cooperation was needed to also assess data availability (from projects or documents) for each of the selected buildings. Each energy service (heating, cooling, domestic hot water (DHW), ventilation systems, and lighting) has been considered, too. Moreover, actual consumption data, related to both electrical and thermal consumption, have been acquired. This is a crucial phase [9- 10], which is often time-consuming, and that, in this case, was held by the Region, which asked to different maintenance companies to search and provide billing from different years.

Based on the information obtained, it was possible to carry on the second macro-phase, during which the identified archetype buildings were modelled through a spreadsheet specifically created and based on UNI/TS 11300 standards. The virtual models of the buildings have allowed: i) to identify EEMs to be implemented both on the passive elements (envelope) and on the active ones (plants); ii) to evaluate potential energy savings and GHGs emissions reduction.

Figure 1 shows the methodology flowchart here described and employed in this work. 


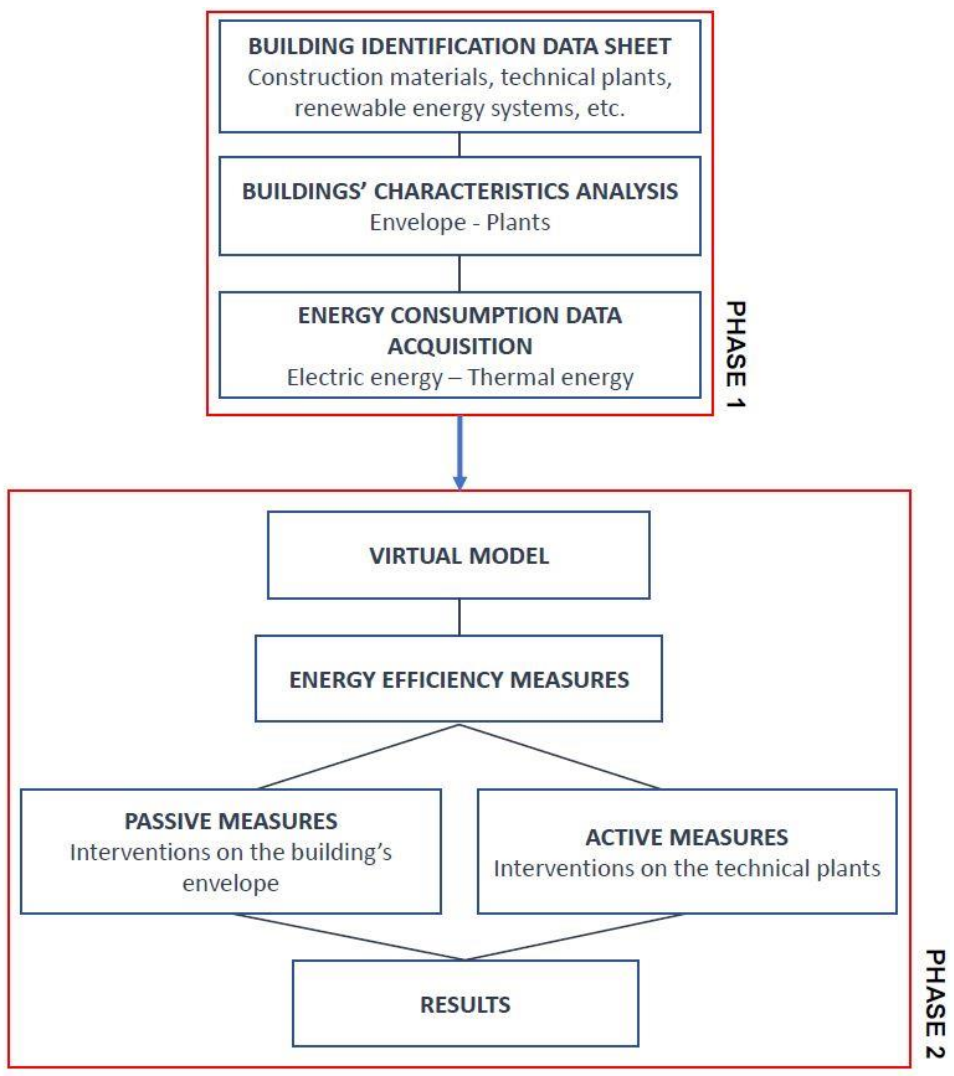

Fig. 1. Methodology flowchart.

\subsection{Buildings description}

The buildings selected by the coordinators of the SHERPA Project for the Abruzzo Region are representative of different age classes and construction types, technological systems, locations and, thus, different climate conditions. Therefore, the 12 selected buildings represent the so-called "archetypes" through which to hypothesize energy optimization guidelines that can be potentially generalized to other public buildings. The analyzed buildings are located in different cities belonging to the four provinces of the Abruzzo Region, as shown in Figure 2, distinguished by different values of Heating Degree Days (HDD). 


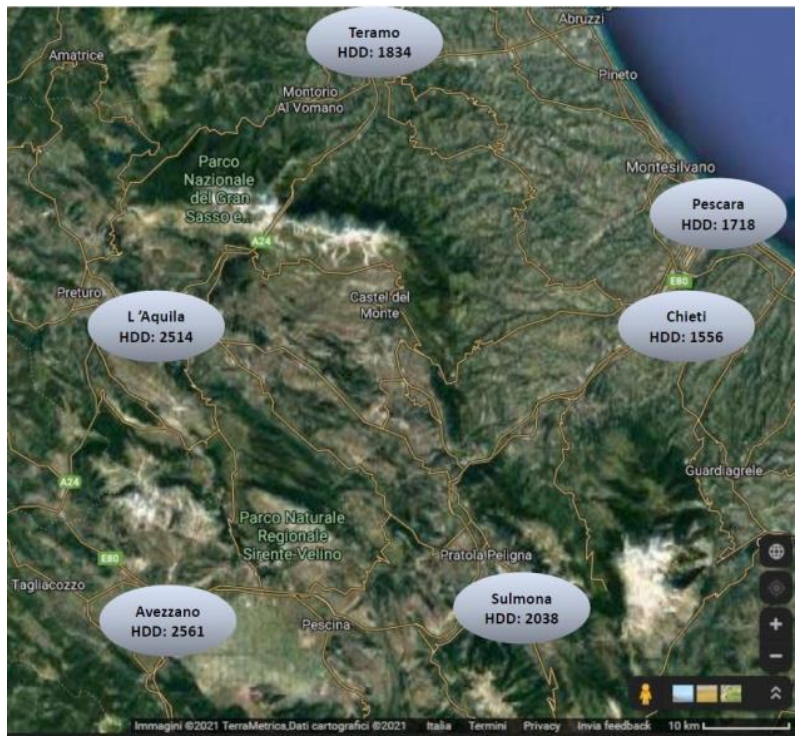

Fig. 2. Buildings' location: the cities where the buildings are located are circled in gray (Authors' elaboration from Google Maps).

The analyzed archetypes, built in different periods - from 1814 to 2000 - are characterized by different envelopes. Most of the buildings are made of masonry, even if reinforced concrete is frequently used. Except for three more recent university buildings in L'Aquila, all others were found to be without insulation. Table 1 summarizes the characteristics listed so far.

Table 1. Buildings' characteristics.

\begin{tabular}{|c|c|c|c|c|c|c|c|}
\hline Building & City & Province & Year & $\begin{array}{l}\text { Floor } \\
\text { area }\left[\mathrm{m}^{2}\right]\end{array}$ & Envelope & Insulation & Windows \\
\hline $\begin{array}{l}\text { Engineering } \\
\text { Campus }\end{array}$ & L'Aquila & L'Aquila & 1999 & 5613.4 & Masonry & Yes & $\begin{array}{l}\text { Double glazing } \\
\text { - aluminum } \\
\text { frame }\end{array}$ \\
\hline $\begin{array}{l}\text { Univaq - } \\
\text { Coppito I }\end{array}$ & L'Aquila & L'Aquila & 2000 & 16525.2 & Masonry & Yes & $\begin{array}{l}\text { Double glazing } \\
- \text { aluminum } \\
\text { frame }\end{array}$ \\
\hline $\begin{array}{l}\text { Univaq - } \\
\text { Coppito II }\end{array}$ & L'Aquila & L'Aquila & 2000 & 16354.4 & Masonry & Yes & $\begin{array}{l}\text { Double glazing } \\
\text { - aluminum } \\
\text { frame }\end{array}$ \\
\hline $\begin{array}{l}\text { Palazzo } \\
\text { Silone }\end{array}$ & L'Aquila & L'Aquila & $\begin{array}{l}1990 / \\
98\end{array}$ & 12700.0 & Concrete & No & $\begin{array}{l}\text { Double glazing } \\
- \text { metal frame }\end{array}$ \\
\hline $\begin{array}{l}\text { Palazzo } \\
\text { Torlonia } \\
\text { (new) }\end{array}$ & Avezzano & L'Aquila & 1970 & 2820.1 & $\begin{array}{l}\text { Prefabricated } \\
+ \text { brick }\end{array}$ & No & n.a. \\
\hline $\begin{array}{l}\text { Palazzo } \\
\text { Torlonia } \\
\text { (old) }\end{array}$ & Avezzano & L'Aquila & 1925 & 2181.1 & Brick & No & $\begin{array}{l}\text { Single glazing - } \\
\text { wooden frame }\end{array}$ \\
\hline Genio civile & Teramo & Teramo & 1950 & 1147.0 & Masonry & No & $\begin{array}{l}\text { Double glazing } \\
\text { - wooden frame }\end{array}$ \\
\hline $\begin{array}{l}\text { M. Delfico } \\
\text { Library }\end{array}$ & Teramo & Teramo & 1814 & 4932.0 & Tuff bricks & No & $\begin{array}{l}\text { Double glazing } \\
\text { - wooden frame }\end{array}$ \\
\hline Genio civile & Pescara & Pescara & $\begin{array}{l}1960 \\
\text { ca. }\end{array}$ & 1782.0 & $\begin{array}{l}\text { Hollow } \\
\text { bricks }\end{array}$ & No & $\begin{array}{l}\text { n.a. }+ \\
\text { aluminum } \\
\text { frame }\end{array}$ \\
\hline Genio civile & Chieti & Chieti & $\begin{array}{l}1950 \\
\text { ca. }\end{array}$ & 2740.0 & Masonry & No & $\begin{array}{l}\text { Double glazing } \\
- \text { aluminum } \\
\text { frame }\end{array}$ \\
\hline
\end{tabular}




\begin{tabular}{|l|l|l|l|l|l|l|l|}
\hline APC & Chieti & Chieti & 1930 & 839.0 & n.a. & No & $\begin{array}{l}\text { Double glazing } \\
- \text { aluminum } \\
\text { frame }\end{array}$ \\
\hline APC & Sulmona & L'Aquila & 1981 & 1094.8 & $\begin{array}{l}\text { Hollow } \\
\text { bricks }\end{array}$ & No & $\begin{array}{l}\text { Double glazing } \\
- \text { aluminum } \\
\text { frame }\end{array}$ \\
\hline
\end{tabular}

The most widely used heating system consists of a low efficiency gas boiler for the energy generation and fan coils or radiators for the energy emission inside the rooms. Control and regulation of the plants are generally manual and centralized, with the exception of two buildings - Palazzo Silone (L'Aquila) and the new Palazzo Torlonia (Avezzano) - in which they take place in every single room through thermostats. The DHW is produced by the same generator that powers the heating system, with the exception of two cases - Genio Civile (Teramo) and Palazzo dell'Agenzia di Promozione Culturale (Sulmona) - in which it is produced by means of electric water heaters. None of the buildings analyzed is equipped with systems to produce energy from renewable sources. Ventilation is natural in all buildings, except for Palazzo Silone which is also equipped with mechanical ventilation. Finally, the lighting systems are characterized by fluorescent lamps with manual on/off switch, apart from Palazzo Silone, where LED lamps are installed.

Table 2 summarizes the main characteristics of the technological plants.

Table 2. Characteristics of technological systems.

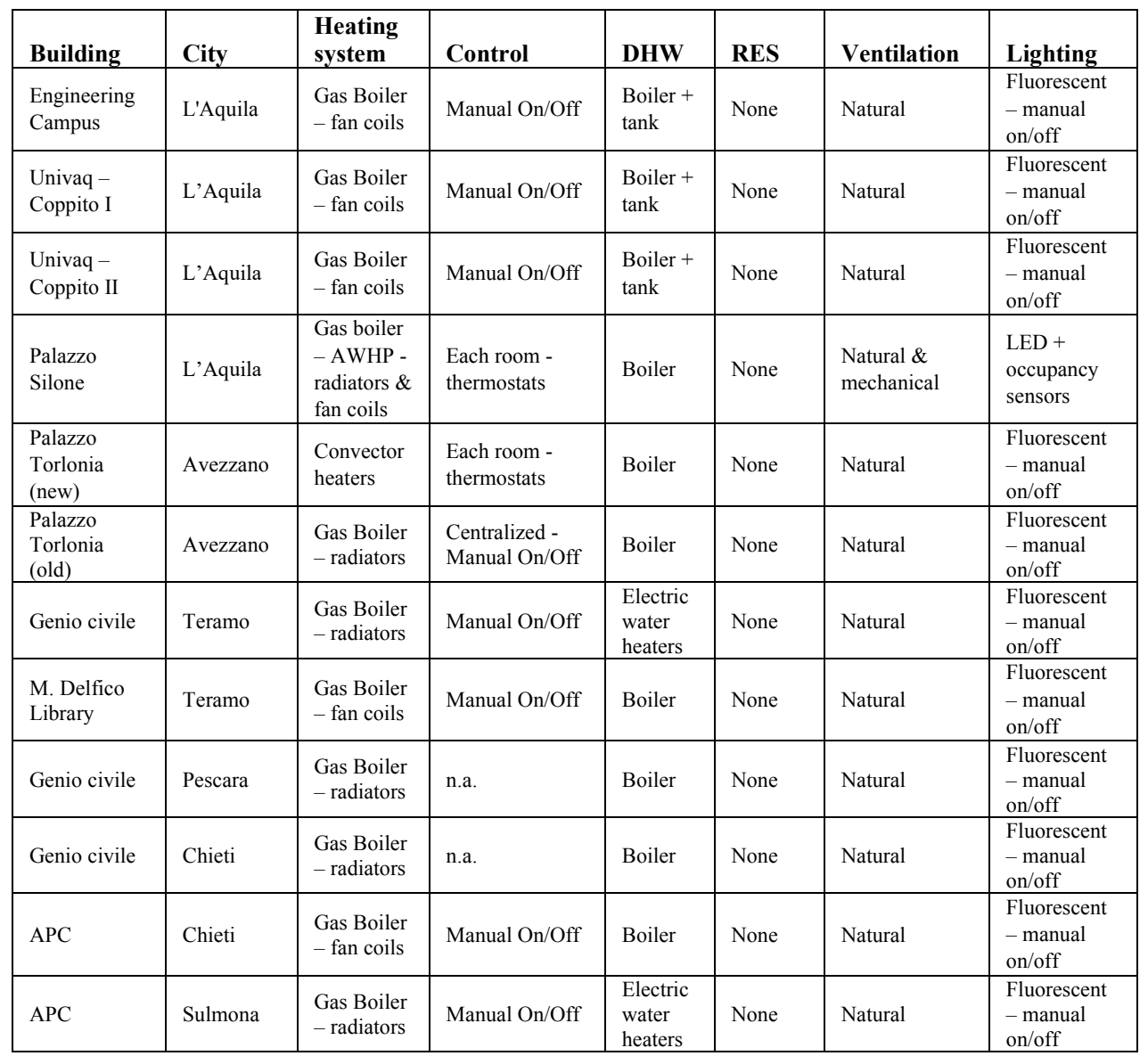




\subsection{Optimization scenarios}

Based on the information acquired, which allowed for an in-depth knowledge of the buildings under analysis, EEMs were identified to improve the performance of both passive and active components.

In particular, the following EEMs have been identified:

1. insulation of opaque vertical surfaces (EEM-1);

2. roof insulation (EEM-2);

3. windows replacement (EEM-3);

4. boiler replacement (EEM-4);

5. air-to-water heat pump (AWHP) installation (EEM-5).

\section{Results and discussion}

The buildings' models in the current condition have showed a very different global energy performance among the various buildings. As indicated by the Italian Ministerial Decree 25 June 2015 [11], the analyses were carried out considering the global non-renewable energy performance index (EPgl,nren), including the energy services present in the buildings. The (EPgl,nren) was found to vary between a minimum value of $126.1 \mathrm{kWh} / \mathrm{m} 2 \mathrm{yr}$ for the Engineering Campus (L'Aquila), and a maximum value of $378.2 \mathrm{kWh} / \mathrm{m} 2 \mathrm{yr}$ for the old Palazzo Torlonia (Avezzano).

The results obtained for all the buildings in the current condition are summarized in Table 3.

Table 3. Energy performance in the current condition.

\begin{tabular}{|l|l|l|l|l|l|}
\hline Building & City & $\begin{array}{l}\text { EP } \\
{\left[\mathbf{k W h} / \mathbf{m}^{2} \mathbf{y r}\right]}\end{array}$ & $\begin{array}{l}\text { Ranking* based } \\
\text { on EP}_{\text {gl,nren }}\end{array}$ & $\begin{array}{l}\mathbf{C O}_{2} \text { emissions } \\
{\left[\mathbf{k g} / \mathbf{m}^{2} \mathbf{y r}\right]}\end{array}$ & $\begin{array}{l}\text { Ranking* based } \\
\text { on } \mathbf{C O}_{2} \text { emissions }\end{array}$ \\
\hline Engineering Campus & L'Aquila & 126.1 & 1 & 25.6 & 1 \\
\hline Univaq - Coppito I & L'Aquila & 141.6 & 3 & 28.9 & 2 \\
\hline Univaq - Coppito II & L'Aquila & 158.4 & 5 & 32.3 & 5 \\
\hline Palazzo Silone & L'Aquila & 136.5 & 2 & 29.1 & 3 \\
\hline $\begin{array}{l}\text { Palazzo Torlonia } \\
\text { (new) }\end{array}$ & Avezzano & 194.6 & 7 & 39.5 & 7 \\
\hline $\begin{array}{l}\text { Palazzo Torlonia } \\
\text { (old) }\end{array}$ & Avezzano & 378.2 & 12 & 75.9 & 12 \\
\hline Genio civile & Teramo & 239.0 & 9 & 48.0 & 9 \\
\hline M. Delfico Library & Teramo & 145.1 & 4 & 29.4 & 4 \\
\hline Genio civile & Pescara & 208.9 & 8 & 42.8 & 8 \\
\hline Genio civile & Chieti & 177.3 & 6 & 36.6 & 6 \\
\hline APC & Chieti & 363.7 & 10 & 73.2 & 10 \\
\hline APC & Sulmona & 366.8 & 11 & 73.7 & 11 \\
\hline * 1: lower value of the considered index; $12:$ higher value of the considered index & \\
\hline
\end{tabular}

Optimization interventions were considered by evaluating the EEMs individually (therefore, combination of two or more EEMs was not considered as to avoid to not accurately consider or underestimate the EEM mutual interference) and the results obtained are shown in Table 4. It is worth noting that the intervention that allows to obtain the greatest energy savings is given by the hypothesis of AWHP installation (EEM-5), which led to a percentage reduction of the global non-renewable energy performance index $\left(\mathrm{EP}_{\mathrm{gl}, \mathrm{nren}}\right)$ 
between - $44.2 \%$ for the building Univaq - Coppito I and $-49.0 \%$ for the old Palazzo Torlonia. Significant effects of energy savings are also given by the hypothesis of modernization of the heat generator through high efficiency condensing gas boiler installation (EEM-4). Among the interventions on passive elements, the insulation of the opaque vertical components (EEM-1) has given the best results. Less interesting seem to be the results obtained by the windows replacement (EEM-3), whose effects are often marginal compared to the current condition, probably due to the reduced window surfaces, a condition typically common for historical buildings.

Table 4. Results of EEMs (values in $\mathrm{kWh} / \mathrm{m}^{2} \mathrm{yr}$ ).

\begin{tabular}{|l|l|l|l|l|l|l|l|}
\hline & & Current & EEM-1 & EEM-2 & EEM-3 & EEM-4 & EEM-5 \\
\hline Building & City & $\mathbf{E P}_{\text {gl,nren }}$ & $\mathbf{E P}_{\text {gl,nren }}$ & $\mathbf{E P}_{\text {gl,nren }}$ & $\mathbf{E P}_{\text {gl,nren }}$ & $\mathbf{E P}_{\text {gl,nren }}$ & EP $_{\text {gl,nren }}$ \\
\hline Engineering Campus & L'Aquila & 126.1 & 97.3 & 117.1 & 110.1 & 109.3 & 68.9 \\
\hline Univaq - Coppito I & L'Aquila & 141.6 & 107.2 & n.p.* & 130.8 & 123.2 & 79.0 \\
\hline Univaq - Coppito II & L'Aquila & 158.4 & 119.2 & n.p. & 139.7 & 137.5 & 87.4 \\
\hline Palazzo Silone & L'Aquila & 136.5 & n.a. & n.a. & n.a. & n.a. & n.a. \\
\hline $\begin{array}{l}\text { Palazzo Torlonia } \\
\text { (new) }\end{array}$ & Avezzano & 194.6 & 143.2 & 147.5 & 189.7 & 168.5 & 105.6 \\
\hline Palazzo Torlonia (old) & Avezzano & 378.2 & 202.3 & 310.1 & 368.6 & 323.8 & 192.7 \\
\hline Genio civile & Teramo & 239.0 & 175.3 & 154.5 & n.p. & 204.8 & 122.3 \\
\hline M. Delfico Library & Teramo & 145.1 & 90.3 & 118.6 & n.p. & 125.6 & 78.7 \\
\hline Genio civile & Pescara & 208.9 & 153.8 & 160.1 & n.p. & 182.6 & 118.8 \\
\hline Genio civile & Chieti & 177.3 & 102.5 & 160.3 & n.p. & 156.0 & 104.7 \\
\hline APC & Chieti & 363.7 & 210.1 & 287.4 & n.p. & 320.2 & 194.1 \\
\hline APC & Sulmona & 366.8 & 213.4 & 316.6 & n.p. & 314.0 & 186.4 \\
\hline$*$ n.p. = non-profitable & & & & & \\
\hline
\end{tabular}

Results can be also read in terms of $\mathrm{EP}_{\mathrm{gl} \text {,nren }}$ reduction (in percentage) for each EEMs, as shown in Table 5, where greener cell represent the higher values, and red cells stand for the lower reduction.

Table 5. EPgl,nren reduction for each EEM.

\begin{tabular}{|l|l|l|l|l|l|l|}
\hline Building & City & EEM-1 & EEM-2 & EEM-3 & EEM-4 & EEM-5 \\
\hline Engineering Campus & L'Aquila & $-22,8 \%$ & $-7,1 \%$ & $-12,7 \%$ & $-13,3 \%$ & $-45,4 \%$ \\
\hline Univaq - Coppito I & L'Aquila & $-24,3 \%$ & n.p. & $-7,6 \%$ & $-13,0 \%$ & $-44,2 \%$ \\
\hline Univaq - Coppito II & L'Aquila & $-24,7 \%$ & n.p. & $-11,8 \%$ & $-13,2 \%$ & $-44,8 \%$ \\
\hline Palazzo Silone & L'Aquila & n.a. & n.a. & n.a. & n.a. & n.a. \\
\hline Palazzo Torlonia (new) & Avezzano & $-26,4 \%$ & $-24,2 \%$ & $-2,5 \%$ & $-13,4 \%$ & $-45,7 \%$ \\
\hline Palazzo Torlonia (old) & Avezzano & $-46,5 \%$ & $-18,0 \%$ & $-2,5 \%$ & $-14,4 \%$ & $-49,0 \%$ \\
\hline Genio civile & Teramo & $-26,7 \%$ & $-35,4 \%$ & n.p. & $-14,3 \%$ & $-48,8 \%$ \\
\hline M. Delfico Library & Teramo & $-37,8 \%$ & $-18,3 \%$ & n.p. & $-13,4 \%$ & $-45,8 \%$ \\
\hline Genio civile & Pescara & $-26,4 \%$ & $-23,4 \%$ & n.p. & $-12,6 \%$ & $-43,1 \%$ \\
\hline Genio civile & Chieti & $-42,2 \%$ & $-9,6 \%$ & n.p. & $-12,0 \%$ & $-40,9 \%$ \\
\hline APC & Chieti & $-42,2 \%$ & $-21,0 \%$ & n.p. & $-12,0 \%$ & $-46,6 \%$ \\
\hline APC & Sulmona & $-41,8 \%$ & $-13,7 \%$ & n.p. & $-14,4 \%$ & $-49,2 \%$ \\
\hline
\end{tabular}


Remark: results for Palazzo Silone were not available, since in 2016 the building has undergone to energy renovation that led to a significant reduction of billing and, therefore, it was not recommended to further intervene to the building itself. This peculiarity has been assessed thanks to the cooperation with the maintenance company. Indeed, for some building, EEM was not profitable from a preliminary analysis.

Results of Table 5 can be re-arranged according to the year of the building, obtaining Table 6, where it is evident that the EEM-1 provides better results for oldest building. Therefore (also bearing in mind that this project aims at identifying appropriate energy optimization strategies for archetype buildings), priority should be given by policy makers to those building whose construction period is earlier and, of course, by considering the building features and characteristics. In this sense, new methodologies, also based on Artificial Intelligence (AI) and on Artificial Neural Network (ANN), could be useful.

Table 6. EPgl,nren reduction for each EEM (sorting by construction year).

\begin{tabular}{|l|l|l|l|l|l|l|l|}
\hline Building & Year & City & EEM-1 & EEM-2 & EEM-3 & EEM-4 & EEM-5 \\
\hline M. Delfico Library & 1814 & Teramo & $-37,8 \%$ & $-18,3 \%$ & n.p. & $-13,4 \%$ & $-45,8 \%$ \\
\hline Palazzo Torlonia (old) & 1925 & Avezzano & $-46,5 \%$ & $-18,0 \%$ & $-2,5 \%$ & $-14,4 \%$ & $-49,0 \%$ \\
\hline APC & 1930 & Chieti & $-42,2 \%$ & $-21,0 \%$ & n.p. & $-12,0 \%$ & $-46,6 \%$ \\
\hline Genio civile & 1950 & Teramo & $-26,7 \%$ & $-35,4 \%$ & n.p. & $-14,3 \%$ & $-48,8 \%$ \\
\hline Genio civile & 1950 ca. & Chieti & $-42,2 \%$ & $-9,6 \%$ & n.p. & $-12,0 \%$ & $-40,9 \%$ \\
\hline Genio civile & 1960 ca. & Pescara & $-26,4 \%$ & $-23,4 \%$ & n.p. & $-12,6 \%$ & $-43,1 \%$ \\
\hline Palazzo Torlonia (new) & 1970 & Avezzano & $-26,4 \%$ & $-24,2 \%$ & $-2,5 \%$ & $-13,4 \%$ & $-45,7 \%$ \\
\hline APC & 1981 & Sulmona & $-41,8 \%$ & $-13,7 \%$ & n.p. & $-14,4 \%$ & $-49,2 \%$ \\
\hline Palazzo Silone & $1990 / 98$ & L'Aquila & n.a. & n.a. & n.a. & n.a. & n.a. \\
\hline Engineering Campus & 1999 & L'Aquila & $-22,8 \%$ & $-7,1 \%$ & $-12,7 \%$ & $-13,3 \%$ & $-45,4 \%$ \\
\hline Univaq - Coppito I & 2000 & L'Aquila & $-24,3 \%$ & n.p. & $-7,6 \%$ & $-13,0 \%$ & $-44,2 \%$ \\
\hline Univaq - Coppito II & 2000 & L'Aquila & $-24,7 \%$ & n.p. & $-11,8 \%$ & $-13,2 \%$ & $-44,8 \%$ \\
\hline
\end{tabular}

\section{Conclusions}

In this paper, the results of the Interreg MED European Project SHERPA concerning the buildings selected in the Abruzzo Region, are presented. The collaboration with the project coordinators of the Abruzzo Region allowed to acquire a large amount of information of the 12 selected public buildings, which can be considered representative, i.e. "archetypes", of part of the regional public building stock. The results of the work have shown that the first phase of document acquisition is very complex and requires great organizational efforts. The energy modelling of the buildings in the actual state and the hypothesis of energy optimization interventions allowed to understand the effectiveness of the EEMs considered. Ranking the effectiveness of the EEMs, it was observed that: the hypothesis of replacing the heat generator with AWHP and condensing gas boiler were greatly effective; slightly less incisive but still very effective were the interventions of thermal insulation of the envelope; differently, the hypothesis of replacing windows resulted not very effective.

In the light of the results obtained, it is interesting to emphasize that the SHERPA Project marks an important milestone in the energy improvement of the European building stock, providing potentially useful information to policy makers called to define strategies and policies for energy optimization in the building sector. 
This work has been realized thanks to the cooperation with the SHERPA project coordinators of the Abruzzo Region. In particular, the authors would like to thank Paola Di Salvatore, regional manager, for her support. The work has been partially funded by the Abruzzo Region.

\section{References}

1. T. de Rubeis, S. Falasca, G. Curci, D. Paoletti, D. Ambrosini, Sensitivity of heating performance of an energy self-sufficient building to climate zone, climate change and HVAC system solutions, Sustain Cities Soc 61, 102300 (2020).

2. T. de Rubeis, I. Nardi, M. Muttillo, D. Paoletti, The restoration of severely damaged churches - Implications and opportunities on cultural heritage conservation, thermal comfort and energy efficiency, J Cult Herit 43, 186-203 (2020).

3. M. Economidou, V. Todeschi, P. Bertoldi, Accelerating energy renovation investments in buildings - Financial \& fiscal instruments across the EU. Publications Office of the European Union, Luxembourg, 2019, ISBN 978-92-76-12195-4, doi:10.2760/086805

4. T. Blazquez, R. Suarez, S. Ferrari, J.J. Sendra, Addressing the potential for improvement of urban building stock: A protocol applied to a Mediterranean Spanish case, Sustain Cities Soc 71, 102967 (2021).

5. SHERPA Joint Action Plan on ERB. Available at https://sherpa.interreg-med.eu/whatwe-achieved/deliverables-

database/detail/?tx_elibrary_pi1\%5Blivrable $\% 5 \mathrm{D}=9208 \&$ tx_elibrary_pi1\%5Baction $\%$

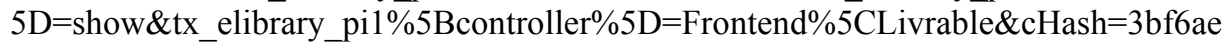
7bd137aa5d919c235ea953d9ae. (Accessed June 8, 2021).

6. Directive 2010/31/EU of the European Parliament and of the Council of 19 May 2010 on the energy performance of buildings (recast).

7. Directive 2012/27/EU of the European Parliament and of the Council of 25 October 2012 on energy efficiency, amending Directives 2009/125/EC and 2010/30/EU and repealing Directives 2004/8/EC and 2006/32/EC.

8. SHERPA Final Brochure. Available at https://sherpa.interregmed.eu/fileadmin/user_upload/Sites/Efficient_Buildings/Projects/SHERPA/Library/Co mmunication/2.3_Coordination_with_2.1_Horizontal_Projects_MED_area/2.3.4_SHE RPA_final_Brochure/SHERPA_Final_Brochure_web_EN.pdf. (Accessed June 8, 2021).

9. V.M. Soto Francés, A. B. Serrano Lanzarote, V. Valero Escribano, M. Navarro Escudero, Improving schools performance based on SHERPA project outcomes: Valencia case (Spain), Energ Build 225, 110297 (2020).

10. D. Palladino, I. Nardi, Approaching the validation of building energy models: billing vs indoor environmental data, E3S Web Conf 197, 02001 (2020).

11. D.M. 25 June 2015. Italian Ministerial Decree. Applicazione delle metodologie di calcolo delle prestazioni energetiche e definizione delle prescrizioni e dei requisiti minimi degli edifici (in Italian). 